\title{
Novel Targets for Antimicrobials
}

\section{Antimikrobiyaller İçin Yeni Hedefler}

\author{
(1) Suchita GUPTA, (1) Vaishali Ravindra UNDALE*, (D) Kedar LAKHADIVE \\ Dr. D.Y. Patil Institute of Pharmaceutical Sciences and Research, Pimpri, Pune, Maharashtra
}

\begin{abstract}
Antimicrobial resistance (AMR) is the phenomenon developed by microorganism on exposure to antimicrobial agents, making them unresponsive. Development of microbial confrontation is a severe rising risk to global community well-being as treatment in addition, management of such resistant microbial infections is difficult and challenging. The situation requires action across all government sectors and society. The change in the molecular target on which antimicrobial drugs act is one of the key mechanisms behind AMR. One of the approaches to battle with AMR can be exploring newer molecular targets in microbes and discovering new molecules accordingly. There are various examples of novel targets such as biomolecules involving in biosynthesis of cell wall, biosynthesis of aromatic amino acid, cell disunion, biosynthesis of fatty acid, and isoprenoid biosynthesis and tRNA synthetases. Fatty acid biosynthesis (FAB) and their enzymes among all the above is the more appealing target for the advancement of new antimicrobial agents. Number of promising inhibitors have been developed for bacterial fatty acid synthesis (FAS) and also few of them are clinically used. Some of these potential inhibitors are found to be used in development of new antibacterial as a lead compound and have been discovered from high throughput screening processes like Platencimycin and their analogue, Platencin. The review majorly encompasses bacterial FAB in type II FAS system and potential inhibitors with respective targets of novel antibacterial.
\end{abstract}

Key words: Drug resistance, antibacterial activities, FAS system, thiolactomycin, platencimycin, platencin

\section{öz}

Antimikrobiyal direnç (AMR), mikroorganizmanın antimikrobiyal ajanlara maruz kalması sonucu geliştirdiği ve organizmayı bu ajanlara tepkisiz hale getiren olgudur. Bu antimikrobiyal ajanlara karşı gelişen direnç, küresel toplum refahı için ciddi bir yükselen risktir, bu tür dirençli mikrobik enfeksiyonların yönetimi zordur. Bu durum, tüm hükümet kademelerinde ve toplumda eyleme geçilmesini gerektirir. Antimikrobiyal ilaçların etki ettiği moleküler hedefteki değişiklik, AMR'nin arkasındaki anahtar mekanizmalardan biridir. AMR ile savaşma yaklaşımlarından biri, mikroplarda daha yeni moleküler hedefleri keşfetmek ve buna göre yeni moleküller keșfetmek olabilir. Hücre duvarının biyosentezine, aromatik amino asit biyosentezine, hücre ayrışmasına, yağ asidinin biyosentezine ve izoprenoid biyosentezine ve tRNA sentetazlarına karşı geliştirilen çeşitli yeni ilaç hedefleri vardır. Yukarıdakilerin tümü arasında yağ asidi biyosentezi (FAB) ve bunların enzimleri, yeni antimikrobiyal ajanların geliştirilmesi için daha çekici bir hedeftir. Bakteriyel yağ asidi sentezi için umut verici inhibitörler geliştirilmiştir ve ayrıca bunlardan bir kısmı klinik olarak kullanılmaktadır. Bu potansiyel inhibitörlerden bazılarının, lider bileşik olarak yeni antibakteriyel geliştirmede kullanıldığı bulunmuştur ve platensimisin ve analoğu platensin gibi yüksek verimli tarama süreçlerinde keşfedilmiştir. Bu derleme büyük ölçüde tip II yağ asidi sentezi sistemindeki bakteriyel FAB'yi ve ilgili yeni antibakteriyel hedeflerle, potansiyel inhibitörleri kapsamaktadır.

Anahtar kelimeler: Illaç direnci, antibakteriyel aktiviteler, FAS sistemi, tiyolaktomisin, platensimisin, platensin

\section{INTRODUCTION}

The agents which destroy or prevent the growth of microbes are termed as antimicrobials. Antimicrobials are classified by various ways depending on mechanism or type of action as bacteriostatic and or bactericidal. ${ }^{\text {Antimicrobial have various }}$ therapeutic implications like endocarditis, gingivitis, prophylactic or suppressive therapy as presurgical antimicrobials, prophylaxis in immunocompromised patients with HIV/AIDS, traumatic injuries, neutropenia etc. ${ }^{2}$ Antimicrobial agents like antibacterial mark vital element of microbial breakdown, thus limiting the bacteria. For example, the $\beta$-lactams, such as penicillin or cephalosporins, inhibit cell-wall synthesis etc. ${ }^{3}$

Antimicrobial resistance (AMR) is the capability of microorganisms to inhibit antimicrobial substances from working against it which results that the standard treatment is ineffective; infections may spread and persist for longer period. ${ }^{4}$ As we see the current scenario of antibiotic use it will increase steadily in recent years and therefore antibacterial played a crucial part in fatality and mournfulness in the nation. ${ }^{5}$ Hence resistance is the major concern now days as resistant organism

*Correspondence: E-mail: vaishali.undale@dypvp.edu.in/vaishaliundale@gmail.com, Phone: +9372435355 ORCID-ID: orcid.org/ 0000-0003-3837-7471 Received: 18.07.2019, Accepted: 21.04.2020

๑Turk J Pharm Sci, Published by Galenos Publishing House. 
may lead to treatment failure, widespread in the community at increasing rate, undetected low level of resistance, added burden to healthcare cost, selection pressure of right antibiotic, threatening return to pre-antibiotic era. ${ }^{6}$

Amongst various types of molecular mechanisms involved in development of AMR, alteration in the molecular targets on which antimicrobials act is one of key mechanism. The researchers in drug discovery process had tried to develop new antimicrobials by altering the functional molecular groups in parent moiety thereby modulating potency and safety of newly designed molecules. This has helped to overcome the AMR to some extent. But still the problem development of AMR persists as microbes are smart enough to mutate and change the molecular mechanism for survival.

Prevention and control strategies will require overcoming from the situation by feasible way called as the evolution of inhibitors of resistant enzymes. These inhibitors can be delivered as a co-drug with the antibiotics, thereby prevent AMR and sustain the antimicrobial activity of the drugs. Another approach to overcome the resistance is bacterial fatty acid synthesis (FAS), which is a necessary goal for antibacterial discovery. The organizational difference of the conserved enzymes and the existence of multiple forms of enzymes mobilizing the similar reactions during the path and create the bacterial FAS which is active against selected target preferably than the established multiple target. Likewise, bacterial FAS inhibitors are found to be narrow-targeting, rather than broad-targeting like old mono-therapeutic and broad-spectrum antibiotics. The narrowtargeting FAS inhibitors found to be fast-developing; resistance is target-based which made it a significant application for antibiotic development. ${ }^{7}$ Despite of advanced antimicrobials with novel targets proceed to be recognized and contributed to the continuing struggle against AMR the intimidation to send back humanity to a circumstance commensurate to the preantibiotic era. Examples of definite target in the areas of cell wall biosynthesis, aromatic amino acid biosynthesis, cell division, two component signal transduction, fatty acid biosynthesis, isoprenoid biosynthesis and tRNA synthetases demonstrates according to characteristics of the above effectiveness were strike in drug finding and depiction of new antibacterial targets. ${ }^{8}$

The review discusses about the novel targets for emerging antimicrobial treatments, featuring important research on which potential to continue to successfully treat bacterial infection relies.

\section{ANTIMICROBIAL: CLASSIFICATION AND ITS TARGETS}

According to their application and spectrum of activity antimicrobials are classified as microbicides that kill microorganisms, whereas bacteriostatic agents inhibit the growth of pathogens and allow the leucocytes and other defense mechanism of the host to confront with immobile invader. The microbicides may show selective toxicity depending on their spectrum of activity. They may act as viricides (killing viruses), bacteriocidic (killing bacteria), algicides (killing algae) or fungicides (killing fungi).

\section{Categorizations of antimicrobial agents}

They are mainly classified into three categories:

- Antibiotics and chemically derived chemotherapeutic agents:

Beta lactam antibiotics, nucleoside antibiotics, aminoglycosides

- Non-antibiotic chemotherapeutic agents:

Disinfectants, antiseptics and preservatives

- Immunological products:

Vaccines, polyclonal antibodies.

\section{Antimicrobial targets}

Antimicrobial drugs interfere chemically with the molecular components of microorganisms that play crucial physiological role in them. They may act as a bactericidal or bacteriostatic. There are discrete ways by which these agents exert their antimicrobial activity such as inhibition protein synthesis, DNA gyrase inhibition, affecting cell wall synthesis or cell membrane function and folic acid synthesis etc. Figure 1 shows the targets with drugs acting on the targets.

Some of the established antimicrobial targets and the drugs with their pathway of action are briefed in Table 1.

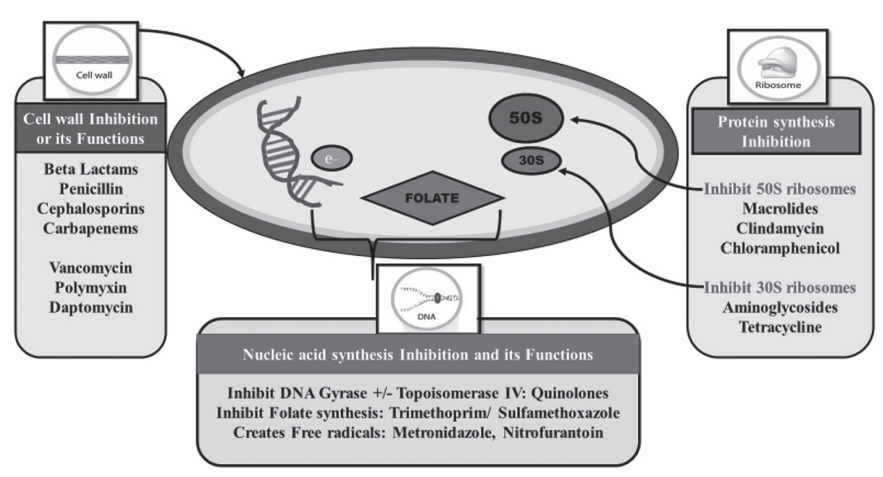

Figure 1. Molecular targets with drugs action on the targets

\section{Development of antibiotics}

In 1930s, the first commercially accessible antibacterial prontosil (sulfonamide) was introduced by German biochemist Gerhard Domagk. Before this, Alexander Fleming identified the primary antibiotic, penicillin, in 1928, which is used to control microbial infections. The period after exhibition of penicillin, is called as "golden era" of antibiotics. After this, many antibiotics were introduced commercially and/or are useful as medicine even for activities other than the antibiotic activity. Antibiotics are used as enzyme inhibitors, antitumor, immunosuppressive, hypolipidemic and antiparasitic agents, in addition to their applications as antibiotics. ${ }^{9}$

The research focusses on discovery of new or novel antibiotics and further modifications in existing antibiotics are still in progress. There are several important reasons why the finding and advancement of antibiotics with innovative structural modules are predominantly important, including the expansion of resistant bacteria and other pathogen. ${ }^{10}$ 


\begin{tabular}{|c|c|c|c|c|}
\hline Primary target & Drug & Drug type & Origin & Pathway affected \\
\hline $\begin{array}{l}\text { Type } 2 \text { topoisomerase } \\
\text { (DNA gyrase), type IV } \\
\text { topoisomerase }\end{array}$ & $\begin{array}{l}\text { Nalidixic acid, } \\
\text { ciprofloxacin, } \\
\text { levofloxacin }\end{array}$ & $\begin{array}{l}\text { DNA synthesis } \\
\text { inhibitors }\end{array}$ & Synthetic & $\begin{array}{l}\text { Deoxyribonucleic acid (DNA) replication, } \\
\text { division of cell, energy generation, citric acid } \\
\text { cycle, ROS formation }\end{array}$ \\
\hline $\begin{array}{l}\text { DNA-dependent } \\
\text { RNA polymerase }\end{array}$ & Rifampicin & $\begin{array}{l}\text { RNA synthesis } \\
\text { Inhibitor }\end{array}$ & Natural and semisynthetic & $\begin{array}{l}\text { RNA transcription, DNA } \\
\text { Replication }\end{array}$ \\
\hline $\begin{array}{l}\text { Penicillin-binding } \\
\text { proteins }\end{array}$ & $\begin{array}{l}\text { Penicillin, } \\
\text { cephalosporins }\end{array}$ & $\begin{array}{l}\text { Inhibitors of cell wall } \\
\text { synthesis } \\
\text { ( } \beta \text {-lactams) }\end{array}$ & $\begin{array}{l}\text { Natural and semi-synthetic forms } \\
\text { of carbonyl lactam ring-containing } \\
\text { azetidinone molecules (from } P \text {. notatum) }\end{array}$ & $\begin{array}{l}\text { Synthesis of cell wall, cell division, enzyme } \\
\text { that breakdown the biological components } \\
\text { called as autolysin activity, ROS formation, } \\
\text { and envelope }\end{array}$ \\
\hline $\begin{array}{l}\text { Peptidoglycan } \\
\text { units (terminal d-Ala-d- } \\
\text { Ala dipeptide) }\end{array}$ & Vancomycin & $\begin{array}{l}\text { Cell wall } \\
\text { synthesis inhibitors } \\
\text { (Glycopeptides) }\end{array}$ & $\begin{array}{l}\text { amino sugar-linked peptide chains } \\
\text { which is natural and semi-synthetic (for } \\
\text { glycopeptides) }\end{array}$ & $\begin{array}{l}\text { Cell wall synthesis, } \\
\text { trans glycosylation, } \\
\text { transpeptidation }\end{array}$ \\
\hline Cell membrane & $\begin{array}{l}\text { Daptomycin and } \\
\text { Polymyxin B }\end{array}$ & $\begin{array}{l}\text { Disruption of cell } \\
\text { membrane function }\end{array}$ & $\begin{array}{l}\text { fatty acid-linked } \\
\text { with peptide chains which is natural and } \\
\text { semi-synthetic obtained from species } S \text {. } \\
\text { roseosporus and } B \text {. polymyxa) }\end{array}$ & $\begin{array}{l}\text { Cell wall synthesis and } \\
\text { envelope two-component } \\
\text { systems }\end{array}$ \\
\hline $30 S$ ribosomes & $\begin{array}{l}\text { Tetracycline and } \\
\text { aminoglycosides }\end{array}$ & $\begin{array}{l}\text { Protein synthesis } \\
\text { inhibitors }\end{array}$ & $\begin{array}{l}\text { It is formed of four-ringed } \\
\text { Polyketides and are natural and semi- } \\
\text { synthetic originated from species } \\
\text { S. aureofaciens }\end{array}$ & $\begin{array}{l}\text { Protein translation occurred through } \\
\text { inhibition of } \\
\text { aminoacyl tRNA binding } \\
\text { to ribosome. }\end{array}$ \\
\hline $50 S$ ribosomes & $\begin{array}{l}\text { Erythromycin and } \\
\text { azithromycin }\end{array}$ & $\begin{array}{l}\text { Protein synthesis } \\
\text { inhibitors }\end{array}$ & $\begin{array}{l}\text { Natural and semi-synthetic forms of } 14- \\
\text { and } 16 \text {-membered lactone rings (from S. } \\
\text { erythraea and S. ambofaciens) }\end{array}$ & $\begin{array}{l}\text { Inhibition of elongation and } \\
\text { translocation process protein translation } \\
\text { happened and by depletion of } \\
\text { free tRNA }\end{array}$ \\
\hline $\begin{array}{l}\text { Simultaneous binding to } \\
\text { bacterial dihydrofolate } \\
\text { reductase }\end{array}$ & $\begin{array}{l}\text { Sulfonamide and } \\
\text { Trimethoprim }\end{array}$ & $\begin{array}{l}\text { Nucleoside } \\
\text { synthesis inhibition }\end{array}$ & Synthetic & $\begin{array}{l}\text { Blocks pathways and inhibit folic acid } \\
\text { metabolism }\end{array}$ \\
\hline
\end{tabular}

\section{Development void}

Today, very fewer novel antibiotics are seemed to be under development. The consequences are seen worldwide as more and more bacterial infections are becoming hard to treat again. This has led to be unavoidable major health problem today. According to Walsh, "no foremost classes of antimicrobials were presented" between 1962 and 2000 which denotes to a modernization gap. Hence due to this innovation gap majority of pharma companies has been pull back their study from this area. ${ }^{11}$ The Figure 2 illustrates the Gap in the Antibiotic development.

\section{Newer targets for antimicrobial agents}

The fruitful growth of various antimicrobials in the 1930s-1960s ${ }^{12}$ established the contented awareness in the therapeutic and methodical societies that microbial infections had been overcome, ensuing in a decreased research in the antimicrobial area. Inappropriately, bacteria altered to their unfavorable novel atmosphere and started surviving even though exposed to the antibiotics. This is a process of gaining resistance that ultimately reduced many of these antimicrobials' noneffective. Presently, communicable diseases are still increasing and may result into one and only major reasons of death globally ${ }^{13-15}$ one of the reasons behind it might be firm decrease in development of new antibacterial agents over the last 20 years. ${ }^{16}$ To fight against this situation, antimicrobial agents with novel mechanisms of action might be helpful. Though, in the last 7 years out of 11 new antimicrobials that were accepted by the Food and Drug Administration, out of two of them acts through a different

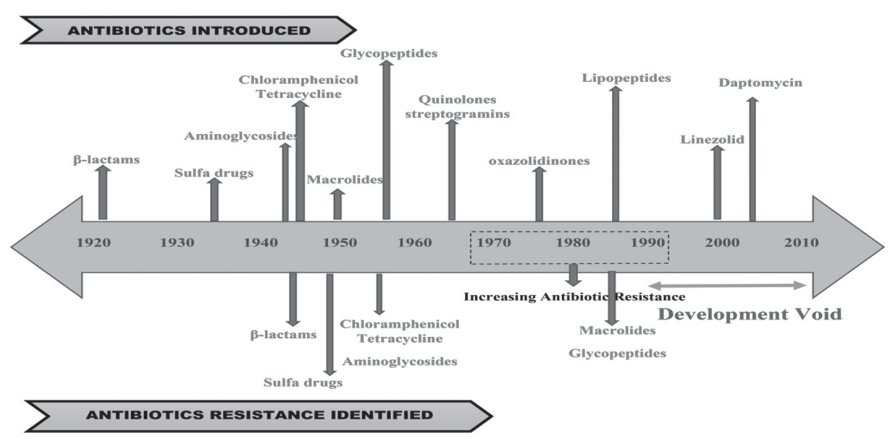

Figure 2. Era of antibiotics development

mechanism: linezolid, an oxazolidinone, and daptomycin, a cyclic lipopeptide, mutually they are used to cure the Grampositive bacterial infections only. Hence there is urgent need of identifying and targeting new targets with novel mechanism that drive a crucial part in the growth of antibiotics dynamic against unaffected pathogens. ${ }^{17-19}$ Table 2 shows difference in single enzyme and multienzyme targets on which antibiotics may act.

As compared to the sole target approach multi-target concept is thought to provide better resistance inhibition, possibility of generating hybrid molecules that may attack two cellular targets concurrently by fastening distinct inhibitors or pharmacophores together to form a single molecule. ${ }^{20,21}$

Though there are so many targets as described above, in the review focusses upon $\beta$-Ketoacyl-acyl carrier protein (ACP) 


\section{Table 2. Newer targets}

Serial

Single enzyme target

Multi enzyme target

number

Sine

1. MurB to MurF enzymes as antibacterial targets

Single pharmacophore, multiple targets

a- Dual inhibitors of DNA gyrase and topoisomerase IV

b- Dual inhibitors of Gram-positive DNA polymerases

c- $\beta$-Ketoacyl-ACP synthases of FAS II

Targets of inhibitors discovered by enzyme screening or desi
a- UppS
b- WalK/WalR
c- LpxC
d- FtsZ
Single-enzyme targets of novel inhibitors in clinical trials
a- Peptidyl deformylase
b- Enoyl-reductases of FAS II
c- Leucyl tRNA synthetases of Gram-negative organisms
d- RNA polymerase in C. difficile

Targeting substrates and cofactors

a- Lipid II and other specific cell wall substrates

b- A vitamin cofactor as target

ACP: Acyl carrier protein, FAS: Fatty acid synthesis

synthases of FAS II which plays a role in microbial fatty acid synthesis. The FAS in microbial cells as following.

\section{Fatty acid biosynthesis}

Beta-ketoacyl-ACP synthase is an enzyme that participates in FAS. It take part in the establishment of aceto-acetyl ACP and it is briefed in Figure 3.

The hugely conserved enzyme that is established in practically all lifecycle on earth as a domain is fatty acid synthase (FAS) also called as Beta-ketoacyl-ACP synthase. ${ }^{22}$ The enzyme plays<smiles>CC(=O)CC(=O)SCCCCCCC(=O)OC(C)=O</smiles>
$\begin{array}{lll}\text { acetyl ACP malonyl ACP } & \text { aceto-acyl ACP }\end{array}$

Fatty acid synthesis: first step is condensation of acetyl ACP and malonyl ACP.

Figure 3. Fatty acid biosynthesis ACP: Acyl carrier protein

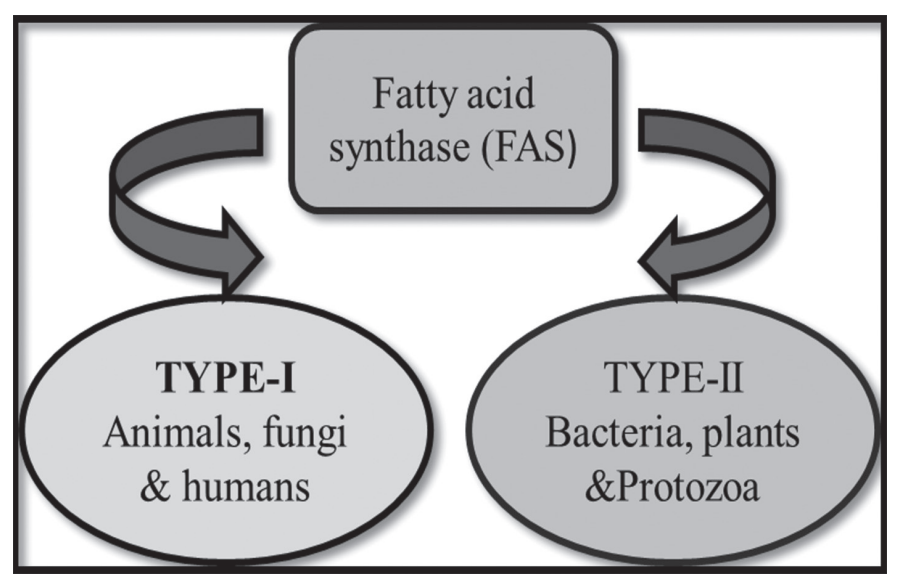

Figure 4. Types of FAS

FAS: Fatty acid synthase a role in the FA elongation series and is tangled in the feedback regulation of the biosynthetic pathway via product inhibition. Two types of FAS enzymes have been identified yet as type-I and type-II shown in Figure 4.

The type I FAS also called associated form which is present in fungi and animals called as multifunctional protein encrypt by a one gene or two genes. Type II FAS also called dissociated type that is found in prokaryotes and plant plastids consists of separate enzymes.

\section{Structure}

Beta-ketoacyl synthase (KAS) consist of two protein domains. Between the $\mathrm{N}$ - and $\mathrm{C}$-terminal domains the active site is situated. Most of the structures participating in dimer formation that constitutes the $\mathrm{N}$-terminal domain and also in the active site cysteine. The substrate restraining and catalysis promoted by residues from both domains. ${ }^{23}$

KAS is a domain on type I FAS, which is a wide enzyme compound that has diversified sections to catalyze various distinct reactions. ${ }^{24}$ Further experimentation of KAS I and II of $E$. coli disclosed that together are homo-dimeric, but KAS II is somewhat bigger. Still, both are tangled in FA metabolism, they have totally different primary structure. ${ }^{25}$ In KAS II, every subunit constitutes a penta-stranded $\beta$ pleated sheet enclosed by several $\alpha$ helices.

The active positions are almost adjacent, which is around $25 \mathrm{~A}^{\circ}$ away, and comprise of a generally aqua phobic pocket. ${ }^{26}$ The occurrence of "fatty acid transport channels" inside the KAS domain that happen into one of many "fatty acid cavities", which basically acts as the active site. ${ }^{27}$

\section{Mechanism}

In the reaction sequence the first step is organized by the KAS category of enzymes that is involved in a nucleophilic substitution by the active-site cysteine residue on the substrate carbonyl. The complete reaction is mediated by the KAS and it splits into distinct valuable phases- 
a- Beginning with ACP, the acyl moiety is transferred to thioester form [but in situation of KAS III it forms acyl-coenzyme A ( $\mathrm{CoA})$ ], to the active-site cysteine residue of the KAS.

b- To produce a reactive carbanion, binding and replacement of carboxyl group with hydrogen atom of the chain widen moiety is required and

C- A new C-C bond of the anion in which carbon is trivalent formed by nucleophilic attack on carbonyl carbon of the acyl moiety. ${ }^{28}$

Both type I and II FAS system can essentially prolong the small chain-length pioneers to the 14-carbon form, additionally the extension of $\mathrm{C} 16$ to C18 ACP, is effectively mobilized by KAS II or FAS II. Hence miscellaneous forms of KAS were identified specifically and plays a crucial part in deciding the structure of the products formed in the particular multi-step's enzyme catalyzed process. ${ }^{29}$ These meaningful characteristics in functioning and arrangement of associated and dissociated form differentiated the type II FAS or dissociated enzymes, as promising goal in the evolution of innovative antibacterial and antiparasitic agents which shows nominal adverse effects in humans. Considering the limitations, words and pages to be published, only KAS III (FabH) are discussed here in detail. ${ }^{30}$

\section{KAS III (FabH)}

In cells, fatty acids playing a major role in cell membrane formation and fatty acid biosynthetic pathway indicated important targets in drug discovery. FAS called as multifunctional enzyme complex system that helps in regulating and processing of FAS. ${ }^{31}$ KAS III is the functional enzymes which initiates the fatty acid synthesis, thus performed a most prominent part in bacterial fatty acid biosynthesis (FAB) and called as condensing enzyme..$^{32-35}$ It is used to mobilize the primary elongation reaction called as Claisen-Schmidt condensation of associated type in microorganisms, plant plastids etc. The FabB and FabF other bacterial condensing enzymes that, work in future in the series, actually showed difference from $\mathrm{FabH}$ in a way that they use acyl-ACP in spite of acetyl-CoA as the primer for further condensation reactions shown in Figure 5.

As a result, FabH seems to show a crucial part in the microbial $\mathrm{FAB}$ cycle because no additional enzyme in the pathway is found

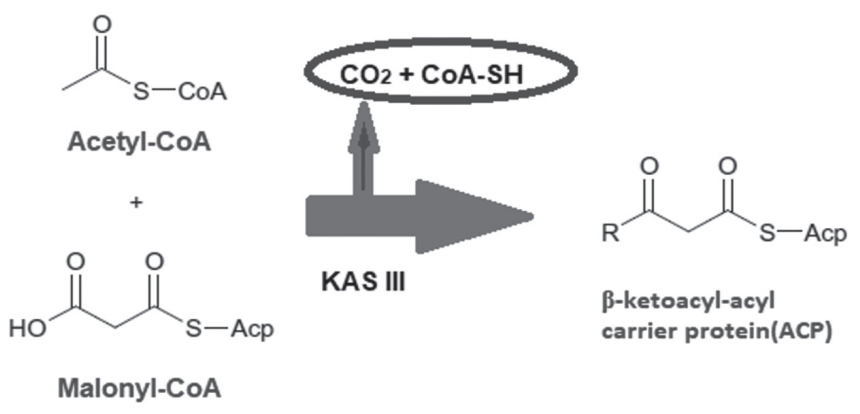

Figure 5. KAS III regulation

The primary condensation step in FAS III regulate by acetoacetyl-ACP synhase (KAS III) KAS: Ketoacyl synthase, FAS: Fatty acid synthase, ACP: Acyl carrier protein, CoA: Coenzyme A to be capable to carry out valuable reaction. ${ }^{36}$ Furthermore, the essential part and 3D assembly of the protein is tremendously protective to the several Gram-positive and Gram-negative bacteria and hence, its inhibitors commit to be dynamic antimicrobials with wide ranging action. ${ }^{37}$

\section{STRUCTURAL EXPLORATION OF $\beta$-Ketoacyl- ACP SYNTHASE III}

$\mathrm{FAB}$ is introduced via KAS. ${ }^{38,39}$ By various reduction and dehydration steps, FAS II cycle helps in prolongation of FA. Between the associated FAS II enzymes, the condensing protein, KAS, is an essential target for novel antibacterial drug design. ${ }^{38,40}$ The three classes of KAS (I, II, and III) have been established in which KAS I is encrypted by FabB and KAS I| by FabF and these are elongation condensing enzymes that prefer acyl-ACP as a primer to abridge with malonyl-ACP..$^{41}$ The function and structures of these two enzymes are same, while significant distinct mechanisms are shown by KAS IIII (encrypt by $\mathrm{FabH}$ ). KAS III regulates primary condensation of acetyl-CoA with malonyl-ACP, and participates as important part of bacterial FAB. ${ }^{40,42}$ The crystal structure of KAS I, II and III shows that they all are dimers having $\alpha-\beta-\alpha-\beta-\alpha$ pleat and their active sites are distinguished by existence of a Cys-His-His triad, in KAS I and II, and a Cys-His-Asn catalytic triad in KAS III. ${ }^{40}$ The concealed active sites of FabH comprised of Cys112, His244 and Asn274. Additionally, Asn343 established near to Asn274, and it was recommended to participate as a major part in the catalysis, Cys112 in the acetyl-CoA/FabH complex structure was found to be acetylated, showing clear proof that, His244 and Asn274 are demanding for decarboxylation and condensation reactions while Cys 112 is the catalytical residue. ${ }^{43}$

Type II FAS reaction pathway: activation, elongation and control $F A B$ takes place in cytosol not in mitochondria. It usually contains a unit called ACP rather than $\mathrm{CoA}$ with reducing agent dihydronicotinamide-adenine dinucleotide phosphate (NADPH) instead of NAD/FAD.

It consists of various steps/stages-

- Transport

- Activation and integrating mechanism

(i) Acetyl CoA carboxylase (ACC)

(ii) FAS complex

- Prolongation of palmitate

(i) Condensation

(ii) Reduction

(iii) Dehydration

(iv) Reduction

- Desaturation of FA

- Regulation of FAB

A. From mitochondria to cytosol Passage of acetyl CoA

In the mitochondria the acetyl CoA is synthesized by two ways shown in Figure 6.

- By $\beta$-oxidation of FA

- By united action of pyruvate dehydrogenase and dihydrolipoyl transacetylase 
Acetyl CoA is moved out from the mitochondria to cytosol and intiate the FAS and this process is takes placed by tricarboxylic carrier protein system in the inner mitochondrial membrane which pushed out the citrate is shown in Figure 7.

\section{Sources of NADPH for Fatty acid synthesis}

- For each particle of Acetyl CoA, one fragment of NADPH is generated that is relocated from mitochodria to the cyotosol.

- NADPH molecules come from the pentose phosphate pathway

\section{B. Activation and synthesis mechanism}

(i) ACC

ACC mediates the first limiting step of FAB and the enzyme biotin which adds $\mathrm{CO}_{2}$, a carboxyl group to methyl end of acetyl CoA. The endothermic reaction described in Figure 8.

\section{(ii) FAS complex}

The seven different reactions catalyzed by multifunctional enzyme by which 2 carbon moieties are linked together from malonyl-CoA and finally formed the palmitoyl-CoA. During the complete synthesis process the formation of palmitate from acetyl CoA it involves total of 7 ATPs and 14 NADPHs.

\section{Elongation of palmitate}

The Precursors needed for elongation reaction gets loaded via thioester derivatives and included following steps with their respective enzymes like condensation, reduction, dehydration and reduction shown in Figure 9.

- From malonyl-ACP there is an inclusion of an acetyl group between the thioester bond of the acetyl-ACP molecule and

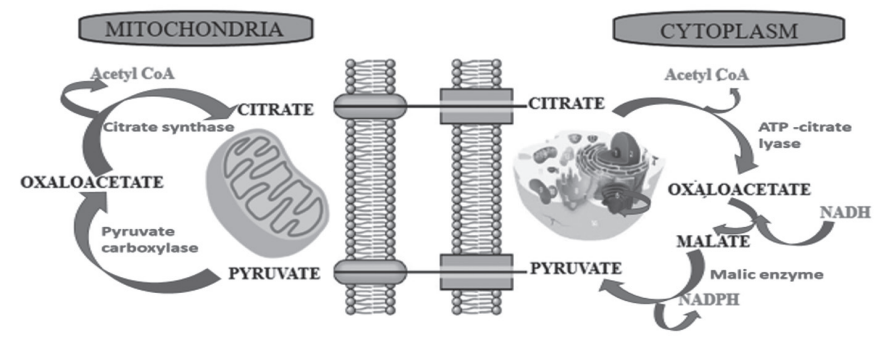

Figure 6. Synthesis of acetyl CoA in mitochondria

CoA: Coenzyme A, NADPH: Dihydronicotinamide-adenine dinucleotide phosphate

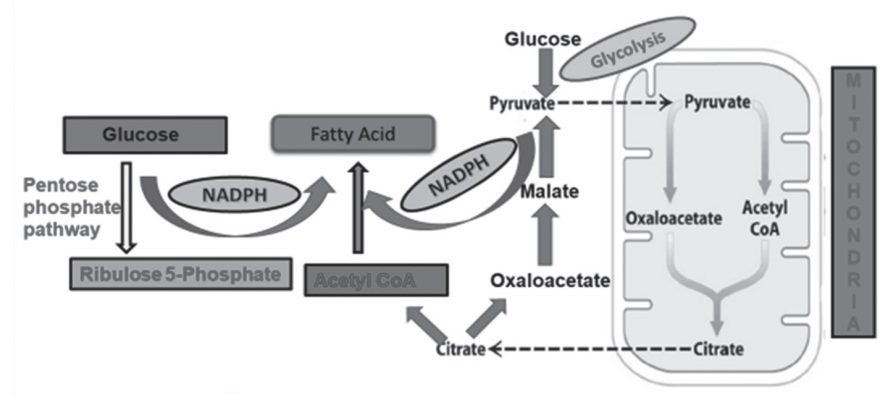

Figure 7. Initiation of fatty acid synthesis in cytosol

CoA: Coenzyme A, NADPH: Dihydronicotinamide-adenine dinucleotide phosphate this reaction is takes place by KAS and this enzyme known as condensing enzyme.

- And when there is a reduction of the Beta-keto group to a Beta-hydroxyl group in coordination with NADPH then this step is mobilized by Beta-keto-ACP reductase.

- During third step of dehydration the reaction is catalyzed by Beta-hydroxy acyl-ACP dehydrase and result into dehydration between the alpha and Beta carbons.

- And lastly there is a reduction by NADPH of the trans double bond and reaction is accomplished by enoyl-ACP reductase.

Various other enzymes like elongases that help to elongates the palmitate to produce many other fatty acids along the reaction and the origin of this enzyme in mitochondria and endoplasmic reticulum.

\section{Desaturation of fatty acids}

Fatty acids get desaturated with the help of enzymes fatty acylCoA desaturase which is terminal desaturases that produce unsaturated fatty acids.

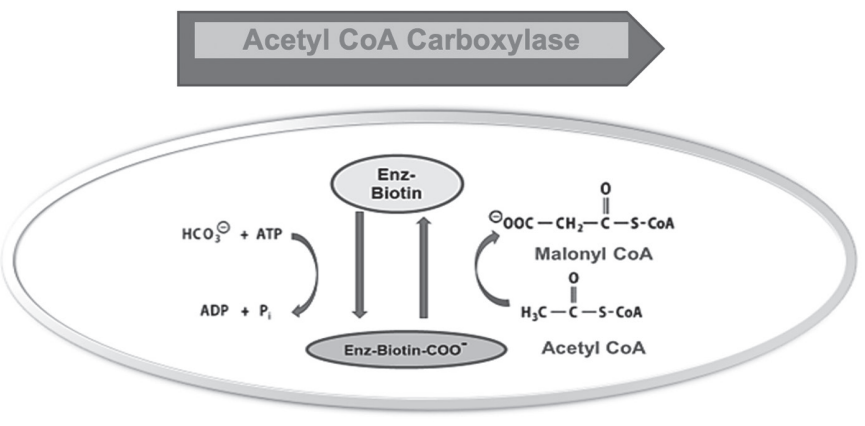

Figure 8. Establishment of malonyl-CoA: most committed steps CoA: Coenzyme A

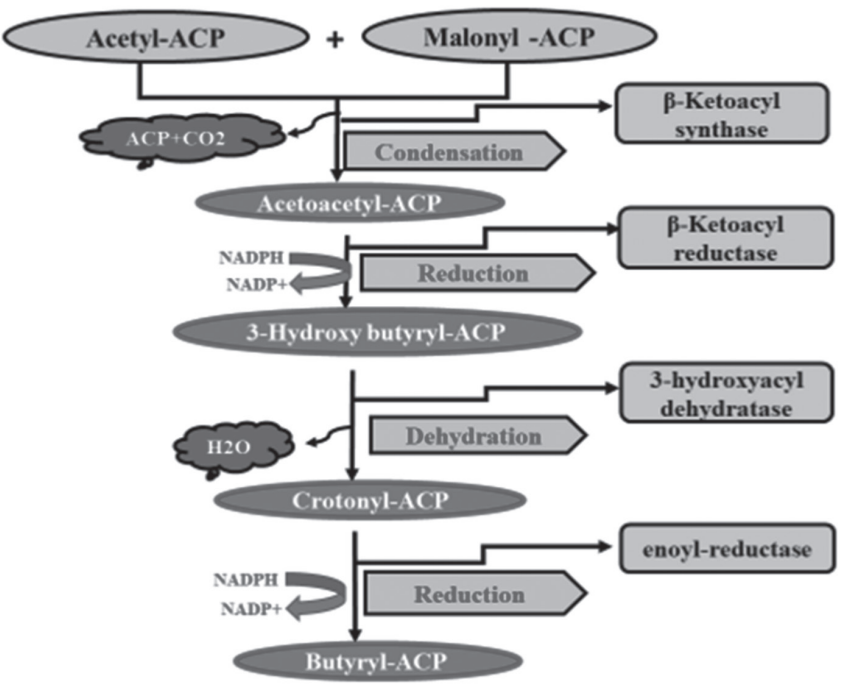

Figure 9. Elongation chain reaction

ACP: Acyl carrier protein, NADPH: Dihydronicotinamide-adenine dinucleotide phosphate 


\section{E. Regulator of $F A B$}

During the FA metabolism of cells, like other metabolic pathways there should have an appropriate control mechanism to meet the energy needs. As FAS can be controlled by either of two ways i.e. partly by long-term regulatory mechanism in which governing the rate of reaction by which any protein incorporates or separate and hence controlled the quantity of enzymes responsible for this and partly by short-term regulatory mechanism like enzymes modification.

\section{VARIOUS INHIBITORS OF $\beta$-KETOACYL ACP SYNTHASES}

The highly conserved, essential and important pathway for survival is type II bacterial FAS. ${ }^{44}$ Thus, the enzymes required during this procedure are found to be most fruitful goal to the advancement of innovative therapeutics. Additionally, to this there are various inhibitors which are used to treat various untreatable or resistant infections like Fabl inhibitors that are recently in preclinical and clinical development against methicillin-resistant S. aureus (MRSA). ${ }^{45-47}$ Along with this there is another appropriate target is FAS II $\beta$-keto (ACP) synthase enzyme. These enzymes show a foremost part in the beginning and continuation phases of FAS II pathway, by mobilizing a decarboxylative Claisen condensation reaction and bacteria has 3 types of KAS enzymes: FabB, FabF and FabH. As FabB and FabF which is also called as KAS I and KAS II which assemble the condensation of malonyl-ACP and acyl-ACP in the elongation cycle and that consist of Cys-His-His catalytic triad, while FabH (KAS III) contains a Cys-His-Asn triad, and is important for the condensation of malonyl-ACP with acetylCoA for beginning of the FASII bacterial cycle. ${ }^{42,48-50}$

\section{Thiolactomycin}

Thiolactomycin (TLM) was first originated from soil samples having a Nocardia species and it is an actinomycetes product having IUPAC name (4S) (2E,5E)-2-4-6-trimethyl-3hydroxy-2,5,7-octatriene-4-thiolide.51,52 TLM showed deprived antibacterial activity and found to be dual inhibitor of $\mathrm{FabH}$ and FabF. TLM is a chiral compound with +ve optical rotation and competitive reversible inhibitor that attached with the malonylACP of the KAS enzymes. According to earlier studies TLM was established as an inhibitor of Gram (+) and Gram (-) FAS. ${ }^{53,54}$ Additionally, efficacious against M. tuberculosis ${ }^{55}$ and other unicellular parasites that contain FAS II. ${ }^{56}$

According to previous studies it was found that TLM particularly restrict the KAS and acetyl-CoA: ACP trans acylase actions in

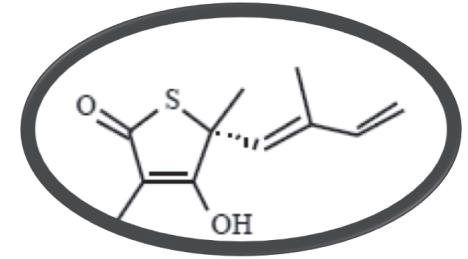

Thiolactomycin (Thiazole derivative) C11H14O2S
E. coli. Besides, TLM mimics the malonyl ACP and prevents the synthases from TLM inhibition on KAS. When done with direct binding studies using fluorescence spectroscopy and provides the confirmation against sensitivity in the given order FabF $>F a b B\rangle \gg F a b H .{ }^{57}$ Majorly two reasons, that showed TLM poor inhibitor of $\mathrm{FabH}$, primary, histidine 298 and 333 in FabB are recouped by His-244 and Asn-274 in FabH, and our FabBTLM structure shows that the two-histidine made strong $\mathrm{H}$ bonds with the antibacterial but the inhibition activity of TLM against different species varies. The isoprenoid moiety in TLM makes its advantageous of a particular aqua-phobic gap which exist in the active sites of both FabB and FabF. ${ }^{58}$ These TLM analogs in plant and mycobacterial fatty-acid synthase systems would be able to explain the results of inhibition in which the isoprenoid moiety regained by different acyl chains. In these organisms, the congeners with lengthy and pliable chains possessed raised activity against FAS II and the lengthy chains might be more thoroughly filled with the possible spaces. ${ }^{59}$ For example, Mycobacterium tuberculosis FabH was 3-time more sensitive to TLM than E. coli FabH. ${ }^{55}$ TLM and the related thiolactones was found to be efficient inhibitors of fatty acid and mycolic acid synthesis in mycobacteria as well as of chloroplast type II FAB. ${ }^{58,60}$ TLM is found to be in toxic in mice and used to treat UTI and intraperitoneal bacterial infections. ${ }^{61}$ Strangely, TLM found to stop the evolution of various protozoan parasites including $T$. gondii and $P$. falciparum. ${ }^{62}$ Newly, TLM is noted to kill trypanosomes by inhibiting the production of myristate. ${ }^{63}$ Myristate is used by the blood-borne form of the parasite to hold the surface glycoproteins that camouflage the parasite from host immune control. This physical awareness shows significant conclusion for the proposal of more effective inhibitors against these enzymes.

\section{Cerulenin (CER)}

A natural product CER is originated from Cephalosporium cerulean. ${ }^{64}$ CER is irreversible inhibitor of FAS of bacteria and eukaryotes or cells ${ }^{65}$ and it also shows therapeutic efficacy in various animal models of yeast infections. ${ }^{66}$ It shows anticancer activity by inhibiting the FAS in mammals which is highly indicative in neoplastic cells and it also exhibit ability to decrease food intake and body weight in mice. ${ }^{67}$ Regardless, of these promising outcomes of CER suggests the root of new therapeutics opportunities, the capability of CER to prevent the mammalian enzymes majorly dabble the interest for further development.

The CER molecule can be differentiate into an aquaphilic head comprising of the functional epoxide ring and a 1,4-diene aqua

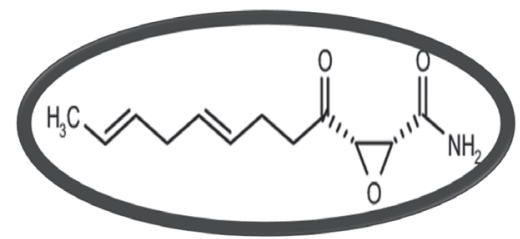

Cerulenin (Aminothiazole derivative) C12H17NO3 
phobic tail. ${ }^{64}$ In case of sensitivity of CER the order of inhibition is $\mathrm{FabB}>\mathrm{FabF} \gg \mathrm{FabH}$ and the reasons of poor inhibition of CER of $\mathrm{FabH}$ is because of that, $\mathrm{FabH}$ is deficient of the substrate hydrophobic pocket to put up in the acyl chain of the drug. This help our judgement that the His-His active site, is different to the FabH His-Asn active site arrangement, which is critical for optimal CER inhibition. When KAS-CER complexes undergo structural analyses, it proposed that CER effectively mimics the transition state of the condensation reaction and confirm many visible features of the early models of CER enzyme inhibition. ${ }^{58}$ The associated type FAS I, of eukaryotes also inhibited by CER by binding to the KAS region of the multi-domain FAS protein. ${ }^{63,68}$ Because of this fact of instability and its toxicity and discouraging pharmacological properties, CER has no practicality as a potential wide-spectrum antibiotic. ${ }^{69}$

\section{Platencimycin (PTM) and platencin (PTN)}

PTM and PTN were originated from the bacterial soil strain Streptomyces platensis with the help of new antisense differential sensitivity screening strategy. ${ }^{70-72}$ Fatty acid ACP synthase II (FabF) which is elongation condensing enzyme selectively inhibited by PTM, whereas PTN is a uniformed dual inhibitor of both FabF and fatty acid ACP synthase III (FabH) which is an initiation condensing enzyme. ${ }^{73}$ The PTM and PTN shows effective, wide-spectrum Gram (+) in vitro activity, including active against antibiotic-resistant bacteria, such as MRSA, vancomycin-resistant Enterococci and vancomycinintermediate $S$. aureus, because of their exclusive antibacterial mechanism. ${ }^{74}$ Basically, both PTM and PTN showing no multi drug-resistance to clinically significant pathogens and show in vivo efficacy without toxicity. ${ }^{75}$ Platensimycin (C24H27NO7, relative molecular mass 441.47), comprises of two distinct structural elements connected by an amide bond. PTM shown to be inhibition selectivity as it does not inhibit DNA, RNA, protein or cell wall biosynthesis at concentrations up to 500 $\mu \mathrm{g} / \mathrm{ml}$. The selectivity of PTM target was first determined within S. aureus strains either showing antisense FabF RNA (AS-fabF) or overexpressing FabF protein. PTM exhibited 200fold greater potency in comparison to CER and similar FabF target selectivity in both assays, reveal that FabF is the major target of PTM for the inhibition of bacterial growth. PTM found to be potent and discriminating inhibitor of mammalian FAS. ${ }^{74}$

PTM and PTN structure shown in Figure 10 having two dissimilar unit attached with a $\mathrm{CO}-\mathrm{NH}$ bond and both possess an 3-amino2,4-dihydroxybenzoic acid (ADHBA) moiety. Elastic amide linkage of propanoic acid is common while the aliphatic cages that are linked to ADHBA moiety are dissimilar. ${ }^{76}$ The aliphatic moieties are composed of 17 carbons with cyclohexanone ring. ${ }^{77}$

\section{Mechanism of action of PTM and PTN}

In FASII, the two classes of decarboxylating condensing enzymes inhibited by PTM and PTN. During the ClaisenSchmidt condensation the chain initiation mediated by condensing enzyme $\mathrm{FabH}$ of acetyl-CoA with malonyl-ACP. The chain elongation is mediated by $\mathrm{FabB} / \mathrm{FabF}$ when the condensation of malonyl-ACP with the growing fatty acylACP takes place. ${ }^{42}$ The utilization of two substrates by $\mathrm{FabH}$ and FabB/FabF in a three-step double displacement reaction mechanism. The cysteine in the active site is covalently transferred in acetyl-CoA in FabH or acyl-ACP in FabB/FabF that forming an acyl-enzyme intermediate and liberating reduced form of CoA or ACP, respectively. The PTM consists of two moiety that is ADHBA moiety which resides inside the malonate binding pocket of FabF and forms possible interactions with catalytic site residues, and other is ketolide moiety that remains in the opening of the catalytic site, partly showing to solvent. ${ }^{70}$ The changes in the organic selectivity's of PTM and PTN must exist in their definite ketolide moieties. The PTM and PTN have similar ADHBA moieties, and have identical catalytic site interactions that is crucial in preventing FA condensation enzymes. In FabF, PTN is still not so much active than PTM, but active as much extent than PTM in $\mathrm{FabH}^{74}$ The selectivity of PTM distinguishing lack of the ether ring. In FabF, during the entry of the active site, PTM makes the hydrogen bond to T270 but not with PTN. Vice-versa, in FabH the analogous region is bound with nonpolar residues, allowing PTN, but not PTM, to inhibit $\mathrm{FabH}^{77}$ described in Figure 11.

\section{Pharmaceutical application}

Most promising antibacterial agents are PTN and PTM because of their particular mechanism

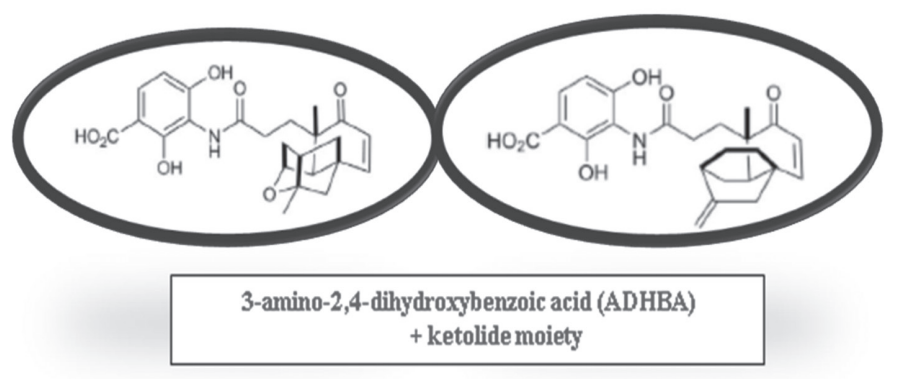

Figure 10. Structure of PTM and PTN

PTM: Platencimycin, PTN: Platencin, ADHBA: 3-amino-2,4dihydroxybenzoic acid

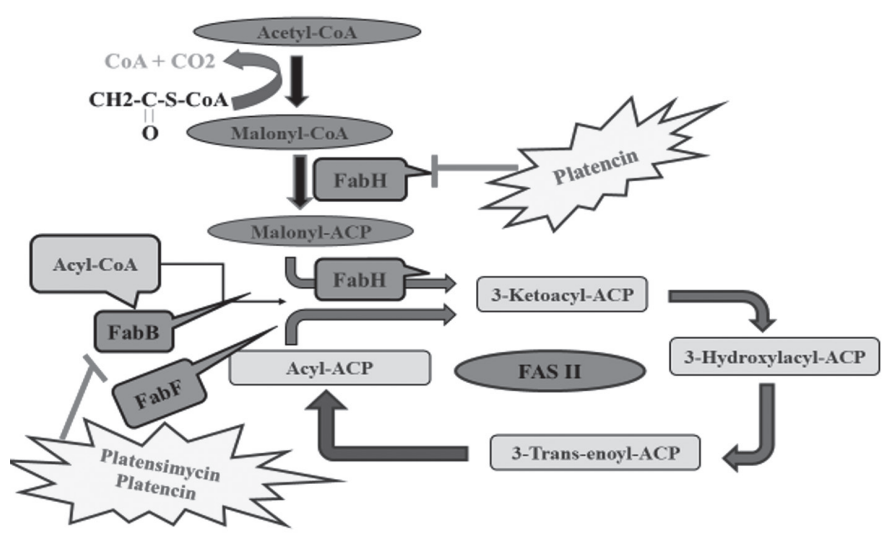

Figure 11. Diagrammatic representation of bacterial fatty acid synthesis cycle (FAS II) red emphasized mark are PTM inhibiting FabF/B and PTN dually inhibiting $\mathrm{FabH}$ and $\mathrm{FabB}$

PTM: Platencimycin, PTN: Platencin 
of action, efficacious in vivo activity and no multi drugresistance with Gram-negative pathogens. But in spite of these promising utilities there are few roadblocks in pharmaceutical advancement such as poor pharmacokinetics and endless discussion on reasonable target for antibacterial therapies of FAS II. ${ }^{74,78}$ Both the natural products found to be unacceptable antibiotics as PTN and PTM both cleared more quickly in vivo and hence to maintain the efficacy need of continuous delivery. The better differentiation between mammalian and bacterial FAB promoted FAS II as a most interesting and fruitful goal for the growth of antibacterial.

PTM developed as an anticipated or potential drug for the management of diabetes and different metabolic irregularities. As both these natural products PTM and PTN have motivated start up and development in the field of biology, medicine, study of enzymes and off course synthetic chemistry.

The distinct antibiotic effectiveness of PTM and PTN might be well-known in clinical trials and their usage in humans for managing with cross- resistance may be acceptable in the upcoming future.

\section{CONCLUSION}

Increased incidences of AMR and unavailability of potential antimicrobials against these resistant microorganisms is going to be one of the major health challenges in future. A variety of potential targets have been explored, the discovery of molecules targeting them has not yet succeeded. In spite of it, the efforts to explore these targets and their modulators are still in process and the future hopes for potential antimicrobials against resistant species of microorganisms remains.

Though the various novel targets like aromatic amino acids, isoprenoids, tRNA synthetases have been identified, fatty acid biosynthesis and the enzymes involved in their biosynthesis are appealing targets in the discovery of antimicrobial drugs. Though number of the FAS inhibitors have been developed only few have reached to clinical use.

The review here claims that bacterial FAS offers a sequence of rational and fascinating targets for antibacterial drugs however the question of how to approach these targets is not yet answered completely. Yet based on the structures of FAS intermediates presently available and the action of the inhibitors it can be estimated that the accessibility of purified b-ketoacyl-ACP syntheses from a variety of bacteria, along with the combination of techniques involving combinatorial chemistry, high-throughput screening, and rational drug design based on crystal structures, will undoubtedly support in the future discovery and development of much needed potent and broad-spectrum antibacterial agents.

PTM and their analogue PTN have been identified as lead compound during the drug development process. They have been characterized as the new classes of potential antibiotics, and their discovery is a success for natural product drug discovery and for new approaches that develop screening sensitivity and specificity. The fact that they inhibit a new target, fatty acid biosynthesis, increases their significance in the combat to stem multidrug resistance against antibiotics that have been in practice for many years.

Conflicts of interest: No conflict of interest was declared by the authors. The authors alone are responsible for the content and writing of this article.

\section{REFERENCES}

1. Mc Dermott PF, Walker RD, White DG. Antimicrobials: modes of action and mechanisms of resistance. Int J Toxicol. 2003;22:135-143.

2. Kang $\mathrm{Cl}$, Song JH. Antimicrobial resistance in Asia: current epidemiology and clinical implications. Infection Chemother. 2013;45:22-31.

3. Kochanski MA, Dwyer DJ, Collins JJ. How antibiotics kill bacteria: from targets to networks. Nature Reviews Microbiology. 2010;8:423-435.

4. Ganguly NK, Arora NK, Chandy SJ, Fairoze MN, Gill JP, Gupta U, Hossain S, Joglekar S, Joshi PC, Kakkar M, Kotwani A, Rattan A, Sudarshan H, Thomas K, Wattal C, Easton A, Laxminarayan R; Global Antibiotic Resistance Partnership (GARP) - India Working Group. Rationalizing antibiotic use to limit antibiotic resistance in India. Indian J Med Res. 2011;134:281-294.

5. Leung E, Weil DE, Raviglione M, Nakatani H, World Health Organization World Health Day Antimicrobial Resistance Technical Working Group. The WHO policy package to combat antimicrobial resistance. Bull World Health Organ. 2011;89:390-392.

6. Ventola CL. The antibiotic resistance crisis: part 1: causes and threats. Pharmacy and Therapeutics. 2015 Apr;40:277-283.

7. Yao J, Rock CO. Bacterial fatty acid-metabolism in modern antibiotic discovery. Biochim Biophys Acta Mol Cell Biol Lipids. 2017;1862:13001309.

8. Maddocks SE. Novel Targets of Antimicrobial Therapies. Microbiol Spectr. 2016;4.

9. Fair RJ, Tor Y. Antibiotics and bacterial resistance in the 21 st century. Perspect Medicin Chem. 2014;6:25-64.

10. Kasanah N, Hamann MT. Development of antibiotics and the future of marine microorganisms to stem the tide of antibiotic resistance. Curr Opin Investig Drugs (London, England:2000). 2004;5:827-837.

11. Silver LL. Challenges of antibacterial discovery. Clin Microbiol Rev. 2011;24:71-109.

12. World Health Organization (WHO) Available from: https://www.who.int/ whr/2004/annex/topic/en/annex_2_en.pdf?ua=1

13. Fischbach MA, Walsh CT. Antibiotics for emerging pathogens. Science. 2009;325:1089-1093.

14. Walsh C. Where will new antibiotics come from? Nat. Rev. Microbiol. 2003;1:65-70.

15. Wenzel RP. The antibiotic pipeline-challenges, costs, and values N Engl J Med. 2004;351:523-526.

16. Spielberg M, Powers JH, Brass EP, Miller LG, Edwards JE Jr. Clin Infect Dis. 2004;38:1279-1286.

17. Lee CS, Allwine DA, Barbachyn MR, Grega KC, Dolak LA, Ford CW, Jensen RM, Seest EP, Hamel JC, Schaadt, RD, Stapert D, Yagi BH, Zurenko GE, Genin MJ. Bioorg Med Chem. 2001;9:3243-3253.

18. Singh U, Raju B, Lam S, Zhou J, Gadwood RC, Ford CW, Zurenko GE, Schaadt RD, Morin SE, Adams WJ, Friis JM, Courtney M, Palandra J, 
Hackbarth CJ, Lopez S, Wu C, Mortell KH, Trias J, Yuan Z, Patel DV, Gordeev MF. Bioorg Med Chem. 2003;13:4209-4212.

19. Reck F, Zhou F, Girardot M, Kern G, Eyermann CJ, Hales NJ, Ramsay RR, Gravestock MB. J Med Chem. 2005;48:499-506.

20. Barbachyn MR, John EM. Recent advances in the discoveryof hybrid antibacterial agents. Annu Rep Med Chem. 2008:43:281-290.

21. Bremner JB, Ambrus JI, Samosorn S. Dual action-based approaches to antibacterial agents. Curr Med Chem. 2007;14:1459-1477.

22. Christensen $C E$, Kragelund $B B$, von Wettstein-Knowles P, Henriksen A. Structure of the human $\beta$-ketoacyl [ACP] synthase from the mitochondrial type II fatty acid synthase. Protein Science. 2007;16:261-272.

23. Witkowski A, Joshi AK, Smith S. Mechanism of the $\beta$-Ketoacyl synthase reaction catalyzed by the animal fatty acid synthase $\dagger$. Biochemistry. 2002; 41:10877-10887.

24. Beld J, Blatti JL, Behnke C, Mendez Ml, Burkart MD. Evolution of acylACP-thioesterases and $\beta$-ketoacyl-ACP-synthases revealed by proteinprotein interactions. J Appl Phycol. 2014;26:1619-1629.

25. Garwin JL, Klages AL, Cronan JE. Structural, enzymatic, and genetic studies of beta-ketoacyl-acyl carrier protein synthases I and II of Escherichia coli. J Biol Chem. 1980;255:11949-11956.

26. Huang W, Jia J, Edwards P, Dehesh K, Schneider G, Lindqvist Y. Crystal structure of beta-ketoacyl-acyl carrier protein synthase II from E. coli reveals the molecular architecture of condensing enzymes. The EMBO Journal. 1998;17:1183-1191.

27. Cui $W$, Liang $Y$, Tian $W$, Ji M, Ma X. Regulating effect of $\beta$-ketoacyl synthase domain of fatty acid synthase on fatty acyl chain length in de novo fatty acid synthesis. Biochim Biophys Acta. 2016;1861:149-155.

28. Witkowski A, Joshi AK, Smith S. Mechanism of the $\beta$-ketoacyl synthase reaction catalyzed by the animal fatty acid synthase. Biochemistry. 2002;41:10877-10887.

29. Campbell JW, Cronan Jr JE. Bacterial fatty acid biosynthesis: targets for antibacterial drug discovery. Annual Reviews in Microbiology. 2001;55:305-332.

30. Zhang JH, Li LZ, Zhu LH. Advances in the research of $\beta$-ketoacyl-ACP synthase III (FabH) inhibitors. Curr Med Chem. 2012;19:1225-1237.

31. Lai CY, Cronan JE. $\beta$-Ketoacyl-acyl carrier protein synthase III (FabH) is essential for bacterial fatty acid synthesis. Journal of Biological Chemistry. 2003;278:51494-503.

32. Khandekar SS, Daines RA, Lonsdale JT. Bacterial $\beta$-ketoacyl-acyl carrier protein synthases as targets for antibacterial agents. Curr Protein Pept Sci. 2003;4:21-29.

33. Heath RJ, Rock CO. Inhibition of beta-ketoacyl-acyl carrier protein synthase III (FabH) by acyl-acyl carrier protein in Escherichia coli. J Biol Chem. 1996;271:10996-11000.

34. Heath RJ, Rock CO. The Claisen condensation in biology. Nat Prod Rep. 2002;19:581-596.

35. Tsay JT, Oh W, Larson TJ, Jackowski S, Rock CO. Isolation and characterization of the $\beta$-ketoacyl-acyl carrier protein synthase III gene (fabH) from Escherichia coli K-12. J Biol Chem. 1992;267:6807-6814.

36. Ali A, Seung JC. A combined approach of docking and 3D QSAR studyof $\beta$-ketoacyl-acyl carrier protein synthase III (FabH) inhibitors. Bioorg Med Chem. 2006;14:1474-1482.

37. Puupponen-Pimia R, Nohynek L, Meier C, Kahkonen M, Heinonen M. Antimicrobial properties of phenolic compounds from berries. J Appl Microbiol. 2001;4:494-507.
38. Veyron-Churlet $R$, Guerrini $O$, Mourey L, Daffe M, Zerbib D. Proteinprotein interactions within the Fatty Acid Synthase-II system of Mycobacterium tuberculosis are essential for mycobacterial viability. Mol Microbiol. 2004;54,:1161-1172.

39. Heath RJ, Rock CO. Inhibition of beta-ketoacyl-acyl carrier protein synthase III (FabH) by acyl-acyl carrier protein in Escherichia coli. J Biol Chem. 1996;3:10996-11000.

40. Khandekar SS, Daines RA, Lonsdale JT. Bacterial beta-ketoacyl-acyl carrier protein synthases as targets for antibacterial agents. Curr Protein Pept Sci. 2003;4:21-29.

41. White SW, Zheng J, Zhang YM, Rock CO. The structural biology of type II fatty acid biosynthesis. Annu Rev Biochem. 2005;74:791-831.

42. Heath RJ, Rock CO. The claisen condensation in biology. Nat Prod Rep. 2002;19:581-596.

43. Choi KH, Kremer L, Besra GS, Rock CO. Identification and substrate specificity of $\beta$-ketoacyl (acyl carrier protein) synthase III (mtFabH) from Mycobacterium tuberculosis. J Biol Chem. 2000;275:28201-28207.

44. Magnuson K, Jackowski S, Rock CO, Cronan JE Jr. Regulation of fatty acid biosynthesis in Escherichia coli. Microbiol. Rev. 1993;57:522-542.

45. Escaich S, Prouvensier L, Saccomani M, Durant L, Oxoby M, Gerusz V, Moreau F, Vongsouthi V, Maher K, Morrissey I, Soulama-Mouze C. The MUT056399 inhibitor of Fabl is a new antistaphylococcal compound. Antimicrob Agents Chemother. 2011;55:4692-4697.

46. Flamm RK, Rhomberg PR, Kaplan N, Jones RN, Farrell DJ. Activity of Debio1452, a Fabi inhibitor with potent activity against Staphylococcus aureus and coagulase-negative Staphylococcus spp., including multidrugresistant strains. Antimicrob Agents Chemother. 2015;59:2583-2587.

47. Park HS, Yoon YM, Jung SJ, Yun IN, Kim CM, Kim JM, Kwak JH. CG400462, a new bacterial enoyl-acyl carrier protein reductase (Fabl) inhibitor. Int J Antimicrob Agents. 2007;30:446-451.

48. Campbell JW, Cronan JE Jr. Bacterial fatty acid biosynthesis: targets for antibacterial drug discovery. Annu Rev Microbiol. 2001;55:305-332.

49. Davies $\mathrm{C}$, Heath RJ, White SW, Rock CO. The 1.8 A crystal structure and active-site architecture of $\beta$-ketoacyl-acyl carrier protein synthase III (FabH) from Escherichia coli. Structure. 2000;8:185-195.

50. Jackowski S, Rock CO. Acetoacetyl-acyl carrier protein synthase, a potential regulator of fatty acid biosynthesis in bacteria. J Biol Chem. 1987;262:7927-7931.

51. Oishi H, Noto T, Sasaki H, Suzuki K, Hayashi T, Okazaki H, Ando K, Sawada M. Thiolactomycin, a new antibiotic. I. Taxonomy of the producing organism, fermentation and biological properties. J. Antibiot (Tokyo). 1982;35:391-395.

52. Sasaki H, Oishi H, Hayashi T, Matsuura I, Ando K, Sawada M. Thiolactomycin, a new antibiotic. II. Structure elucidation. J. Antibiot (Tokyo). 1982;35:396-400.

53. Borgaro, JG, Chang A, Machutta CA, Zhang X, Tonge, PJ. Substrate recognition by $\beta$-ketoacyl-ACP synthases. Biochemistry. 2011, 50, 10678-10686.

54. Hamada S, Fujiwara T, Shimauchi H, Ogawa T, Nishihara T, Koga T. Oral Microbiol Immunol. 1990;5:340-345.

55. Choi KH, Kremer L, Besra GS, Rock CO. J Biol Chem. 2000;275: 2820128207.

56. Morita YS, Paul KS, Englund PT. Specialized fatty acid synthesis in African trypanosomes: Myristate for GPI anchors. Science. 2000;288:140-143. 
57. Price AC, Choi KH, Heath RJ, Li Z, White SW, Rock CO. Inhibition of beta-ketoacyl-acyl carrier protein synthases by thiolactomycin and cerulenin. Structure and mechanism. J Biol Chem. 2001;276:65516559.

58. Jones AL, Herbert D, Rutter AJ, Dan er JE, Harwood JL. J Biochem 2000;347:205-209.

59. Kremer L, Douglas JD, Baulard AR, Morehouse C, Guy MR, Alland D, Dover LG, Lakey JH, Jacobs WR Jr, Brennan PJ, Minnikin DE, Besra GS. Thiolactomycin and related analogues as novel anti-mycobacterial agents targeting KasA and KasB condensing enzymes in Mycobacterium tuberculosis. J Biol Chem. 2000;275:16857-16864.

60. Slayden RA, Lee RE, Armour JW, Cooper AM, Orme IM, Brennan PJ, Besra GS. Antimycobacterial action of thiolactomycin: an inhibitor of fatty acid and mycolic acid synthesis. Antimicrob Agents Chemother. 1996;40:2813-2819.

61. McFadden JM, Frehywot GL, Townsend CA. A flexible route to (5 R)thiolactomycin, a naturally occurring inhibitor of fatty acid synthesis. Organic Letters. 2002;4:3859-3862.

62. Waller RF, Keeling PJ, Donald RG, Striepen B, Handman E, Lang-Unnasch N, Cowman AF, Besra GS, Roos DS, McFadden Gl. Nuclear-encoded proteins target to the plastid in Toxoplasma gondii and Plasmodium falciparum. Proc Natl Acad Sci USA. 1998;95:12352-12357.

63. Morisaki N, Funabashi H, Shimazawa R, Furukawa J, Kawaguchi A, Okuda S, Iwasaki S. Effect of side-chain structure on inhibition of yeast fatty-acid synthase by cerulenin analogues. Eur $\mathrm{J}$ Biochem. 1993;211:111-115.

64. Omura S, Katagiri M, Nakagawa A, Sano Y, Nomura S. Studies on cerulenin. V. Structure of cerulenin. J Antibiot. 1967;20:349-354.

65. D'Agnolo G, Rosenfeld IS, Awaya J, Omura S, Vagelos PR. Inhibition of fatty acid synthesis by the antibiotic cerulenin. Specific inactivation of beta-ketoacyl-acyl carrier protein synthetase. Biochim Biophys Acta. 1973;326:155-156

66. Nomura $\mathrm{S}$, Horiuchi $\mathrm{T}$, Omura $\mathrm{S}$, Hata $\mathrm{T}$. The action mechanism of cerulenin. I. Effect of cerulenin on sterol and fatty acid biosynthesis in yeast. J Biochem. 1972;71:783-796.

67. Loftus TM, Jaworsky DE, Frehywot GL, Townsend CA, Ronnett GV, Lane MD, Kuhajda FP. Reduced food intake and body weight in mice treated with fatty acid synthase inhibitors. Science. 2000;288:2379-2381.

68. Kuhajda FP, Pizer ES, Li JN, Mani NS, Frehywot GL,Townsend CA. Synthesis and antitumor activity of an inhibitor of fatty acid synthase. Proc Natl Acad Sci USA. 2000;97:3450-3454.

69. Parrish NM, Kuhajda FP, Heine HS, Bishai WR, Dick, JD. Antimycobacterial activity of cerulenin and its effects on lipid biosynthesis. J Antimicro Chemo. 1999;43:219-226.

70. Wang J, Soisson SM, Young K, Shoop W, Kodali S, Galgoci A, Painter R, Parthasarathy G, Tang Y, Cummings R, Ha S, Dorso K, Moty M,
Jayasuriya H, Ondeyka J, Herath K, Zhang C, Hernandez L, Allocco J, Basilio A, Tormo JR, Genilloud O, Vicente F, Pelaez F, Colwell L, Lee SH, Michael B, Felcetto T, Gill C, Silver LL, Hermes JD, Bartizal K, Barrett J, Schmatz D, Becker JW, Cully D, Singh SB. Platensimycin is a selective FabF inhibitor with potent antibiotic properties. Nature. 2006; 441:358-361.

71. Young K, Jayasuriya H, Ondeyka JG, Herath K, Zhang C, Kodali S, Galgoci A, Painter R, Brown-Driver V, Yamamoto R, Silver LL, Zheng Y, Ventura JI, Sigmund J, Ha S, Basilio A, Vicente F, Tormo JR, Pelaez F, Youngman P, Cully D, Barrett JF, Schmatz D, Singh SB,Wang J. Discovery of $\mathrm{FabH} / \mathrm{FabF}$ Inhibitors from Natural Products. Antimicrob Agents Chemother. 2006;50:519-526.

72. Zhang $\mathrm{CW}$, Ondeyka J, Herath $\mathrm{K}$, Jayasuriya $\mathrm{H}$, Guan ZQ, Zink DL, Dietrich L, Burgess B, Ha SN, Wang J, Singh SB. Platensimycin and platencin congeners from Streptomyces platensis. J Nat Prod. 2011;74:329-340.

73. Martens E, Demain AL. Platensimycin and platencin: Promising antibiotics for future application in human medicine. J Antibiot. 2011;64:705-710.

74. Wang J, Kodali S, Lee SH, Galgoci A, Painter R, Dorso K, Racine F, Motyl M, Hernandez L, Tinney E, Colletti SL, Herath K, Cummings R, Salazar O, González I, Basilio A, Vicente F, Genilloud O, Pelaez F, Jayasuriya H, Young K, Cully DF, Singh SB. Discovery of platencin, a dual FabF and FabH inhibitor with in vivo antibiotic properties. Proc Natl Acad Sci USA. 2007;104:7612-7616.

75. Peterson RM, Huang T, Rudolf JD, Smanski MJ, Shen B. Mechanisms of self-resistance in the platensimycin-and platencin-producing Streptomyces platensis MA7327 and MA7339 strains. Chem Biol. 2014:21:389-397.

76. Singh $\mathrm{SB}$, Jayasuriya $H$, Ondeyka JG, Herath $\mathrm{KB}$, Zhang $C$, Zink DL, Tsou NN, Ball RG, Basilio A, Genilloud O, Diez MT, Vicente F, Pelaez F, Young K, Wang J. Isolation, structure, and absolute stereochemistry of platensimycin, a broad-spectrum antibiotic discovered using an antisense differential sensitivity strategy. J Am Chem Soc. 2006;128:11916-11920

77. Jayasuriya H, Herath KB, Zhang C, Zink DL, Basilio A, Genilloud O, Diez MT, Vicente F, Gonzalez I, Salazar O, Pelaez F, Cummings R, Ha S, Wang J, Singh SB. Isolation and structure of platencin: a FabH and FabF dual inhibitor with potent broad-spectrum antibiotic activity. Angew Chem Int Ed. 2007;46:4684-4688.

78. Wang J, Soisson SM, Young K, Shoop W, Kodali S, Galgoci A, Painter R, Parthasarathy G, Tang YS, Cummings R, Ha S, Dorso K, Motyl M Jayasuriya H Ondeyka J, Herath K, Zhang C, Hernandez L, Allocco J, Basilio A, Tormo JR, Genilloud O, Vicente F, Pelaez F, Colwell L, Lee SH, Michael B, Felcetto T, Gill C, Silver LL, Hermes JD, Bartizal K, Barrett J, Schmatz D, Becker JW, Cully D, Singh SB. Platensimycin is a selective FabF inhibitor with potent antibiotic properties, Nature. 2006;441:358-361. 